\title{
Photovoltaic Performance of Spray-Coated Zinc Oxide Nanoparticles Sensitized With Metal-Free Indoline Dyes
}

\author{
Boateng Onwona-Agyeman ${ }^{1}$, Motoi Nakao ${ }^{2} \&$ Takuya Kitaoka ${ }^{3}$ \\ ${ }^{1}$ Department of Materials Science and Engineering, University of Ghana, Legon-Accra, Ghana \\ ${ }^{2}$ Department of Basic Science, Kyushu Institute of Technology, 1-1 Sensui, Tobata-ku, Kitakyushu, Japan \\ ${ }^{3}$ Department of Agro-environmental Sciences, Kyushu University, 6-10-1 Hakozaki, Higashi-ku, Fukuoka, \\ Japan
}

Correspondence: Takuya Kitaoka, Professor, Ph.D., Department of Agro-environmental Sciences, Kyushu University, 6-10-1 Hakozaki, Higashi-ku, Fukuoka 812-8581, Japan. Tel/Fax: 81-92-642-2993. E-mail: tkitaoka@agr.kyushu-u.ac.jp

Received: November 13, 2013 Accepted: November 28, 2013 Online Published: December 19, 2013

doi:10.5539/jmsr.v3n1p87

URL: http://dx.doi.org/10.5539/jmsr.v3n1p87

\begin{abstract}
Photovoltaic properties of nano-sized zinc oxide $(\mathrm{ZnO})$ films sensitized with a conventional ruthenium complex (N719) and two metal-free organic indoline dyes (D-149 and D-205) were compared. The ZnO nanoparticles were deposited on transparent conductive aluminum-doped $\mathrm{ZnO}$ coated glass substrates (AZO) by spray-coating deposition method and then annealed in air at $500{ }^{\circ} \mathrm{C}$. Using the $\mathrm{ZnO}$-coated $\mathrm{AZO}$ as transparent conductive substrates, dye-sensitized solar cells (DSCs) were prepared with the N719, D149 and D205 dyes as the sensitizers. The photoaction spectra of the incident photon-to-current conversion efficiency (IPCE) of the DSCs revealed that the indoline-sensitized solar cells were higher and broader than the ruthenium-sensitized solar cell in the photo-absorption behavior. Under AM 1.5 simulated sunlight $\left(1000 \mathrm{~W} \mathrm{~m}^{-2}\right)$, the indoline-sensitized $\mathrm{ZnO}$ solar cells yielded solar-to-electric energy conversion efficiency of 3.02 and $2.26 \%$ for the D-205 and D-149 respectively, while the $\mathrm{N} 719$ sensitized $\mathrm{ZnO}$ recorded only $0.97 \%$. The superior performance of the indoline-sensitized solar cells was attributed to mainly higher sunlight harvesting efficiency of these metal-free organic dyes.
\end{abstract}

Keywords: $\mathrm{ZnO}$ nanoparticle, metal-free dye, transparent conductor, solar cell

\section{Introduction}

Commercially available solar cells are currently based on inorganic semiconductor (silicon, cadmium-terullide CdTe and copper-indium-gallium-selenide CIGS) materials. These inorganic semiconductor materials are expensive and besides their device fabrication processes are tedious and complex. Therefore, solar cells based on organic materials appear to be highly promising and low cost alternative for the photovoltaic energy sector. Dye-sensitized solar cell (DSC) is a photovoltaic device that relies on a dye as the sunlight-absorber material, a porous oxide semiconductor film coated on a transparent conducting film, an electrolyte containing a redox couple and a counter electrode. The dye first absorbs light, producing excitons which dissociate at the dye-semiconductor interface, resulting in the injection of photoelectrons into the conduction band of the porous semiconductor. While the electron is transported through the porous semiconductor to the external circuit, the hole migrates through the electrolyte solution to the counter electrode where it recombines with an electron. Therefore, the dye plays a critical role in the operation of the DSC. The development efforts in the synthesis of dye sensitizers can be grouped into two areas, namely the synthesis of ruthenium complex dyes such as N3 (Grätzel, 2004; Nazeerudin et al., 1993), N719 (Nazeerudin et al., 2002), Z907 (Wang et al., 2002; Wang et al., 2003) and black dye (Nazeerudin et al., 2001; Chiba et al., 2006) and the synthesis of metal-free organic donor dyes (Chen et al., 2010; Guerin et al., 2010; Tefashe et al., 2010; Chen et al., 2011). The former class of compounds contains expensive ruthenium metal and requires careful synthesis steps, while the latter can be prepared rather inexpensively by following designed rules. At present, the state-of-the-art DSCs based on ruthenium complex dye as the sensitizer and $\mathrm{TiO}_{2}$ semiconductor have an overall power conversion efficiency of more than 11\% under standard Air Mass 1.5 (AM 1.5) illumination (Nazeerudin et al., 2005; Chiba et al., 2006). However, the molar extinction coefficients of these dyes are low compared with most metal-free organic dyes 
(Wang et al., 2005). In contrast to the ruthenium complex dyes, different light absorbing groups can be introduced into the organic framework of the metal-free dye in order to tune the spectral absorption over wide wavelength and also to achieve high extinction coefficients. Major progress has been made in the use of metal-free organic dyes as sensitizers in DSCs with the highest solar-to-electric power conversion efficiency exceeding $8 \%$ (Ito et al., 2006; Ito et al., 2008). In our previous work, we have reported the preparation and characterization of sputtered aluminum and gallium co-doped zinc oxide $(\mathrm{ZnO})$ films as conductive substrates in dye-sensitized solar cells (Onwona-Agyeman et al., 2013). In this work, we have compared two metal-free indoline dyes (D149 and D205) and a ruthenium complex dye (N719) to sensitize the film composites on which $\mathrm{ZnO}$ nanoparticles were deposited by spray-coating method. The $\mathrm{ZnO}$ photoelectrodes were formed on transparent and conductive aluminum-doped zinc oxide films (AZO) instead of the usual fluorine-doped tin oxide (FTO) to eliminate lattice mismatch and thermal expansion differences during heat treatments. The photovoltaic properties of the sensitized $\mathrm{ZnO}$ DSCs were evaluated under standard AM 1.5 simulated sunlight $\left(1000 \mathrm{~W} \mathrm{~m}^{-2}\right)$ illumination.

\section{Experimental Procedure}

The AZO films were prepared by radio frequency (rf) magnetron sputtering using a mixed ceramic target consisting of $\mathrm{ZnO}\left(97.5\right.$ wt. \%) and $\mathrm{Al}_{2} \mathrm{O}_{3}(2.5$ wt. \%) (Hirahara et al., 2012). During the deposition of the AZO film, rf power was kept at $100 \mathrm{~W}$, substrate temperature at $300{ }^{\circ} \mathrm{C}$ and sputter pressure at $3 \mathrm{~Pa}$. The resultant AZO films prepared under these conditions yielded films with sheet resistance of $8 \Omega / \mathrm{sq}$ and the average transmittance of $82 \%$ within the wavelength range of $400-800 \mathrm{~nm}$. ZnO powder (20 nm particle size, Wako Chemicals, Japan), few drops of glacial acetic acid and $40 \mathrm{ml}$ of ethanol were mixed and ultrasonically dispersed for $10 \mathrm{~min}$. The mixture was then sprayed onto AZO substrates heated at $150{ }^{\circ} \mathrm{C}$ and subsequently annealed in air at $500{ }^{\circ} \mathrm{C}$ for $30 \mathrm{~min}$. The resultant $\mathrm{ZnO}$ photoelectrodes (active cell area $\sim 0.25 \mathrm{~cm}^{2}$ ) were then immersed separately in a mixture of acetonitrile/tert-butanol (volume 1:1) containing either $5 \times 10^{-4} \mathrm{M}$ indoline (D149 or $\mathrm{D} 205$ ) or ruthenium dyes for $12 \mathrm{~h}$. The dye-coated $\mathrm{ZnO}$ photoelectrodes were removed, rinsed with acetonitrile and allowed to dry. Finally, the $\mathrm{ZnO}$ photoelectrodes were sandwiched with a platinum-coated counter electrode and the intervening space filled with an electrolyte solution ( $0.1 \mathrm{M} \mathrm{LiI}, 0.05 \mathrm{M} \mathrm{I}_{2}, 0.5 \mathrm{M}$ tert-butyl pyridine, 0.6 $\mathrm{M}$ dimethylpropylimidazolium iodide in methoxyacetonitrile). The photocurrent action spectra $\left(50 \mu \mathrm{W} \mathrm{cm} \mathrm{cm}^{-2}\right)$ and the current-voltage (I-V) characteristics of the solar cells at AM $1.5\left(1000 \mathrm{~W} \mathrm{~m}^{-2}\right)$ simulated sunlight irradiation were recorded with a calibrated solar cell evaluation system (JASCO, CEP-25BX).

\section{Results and Discussions}

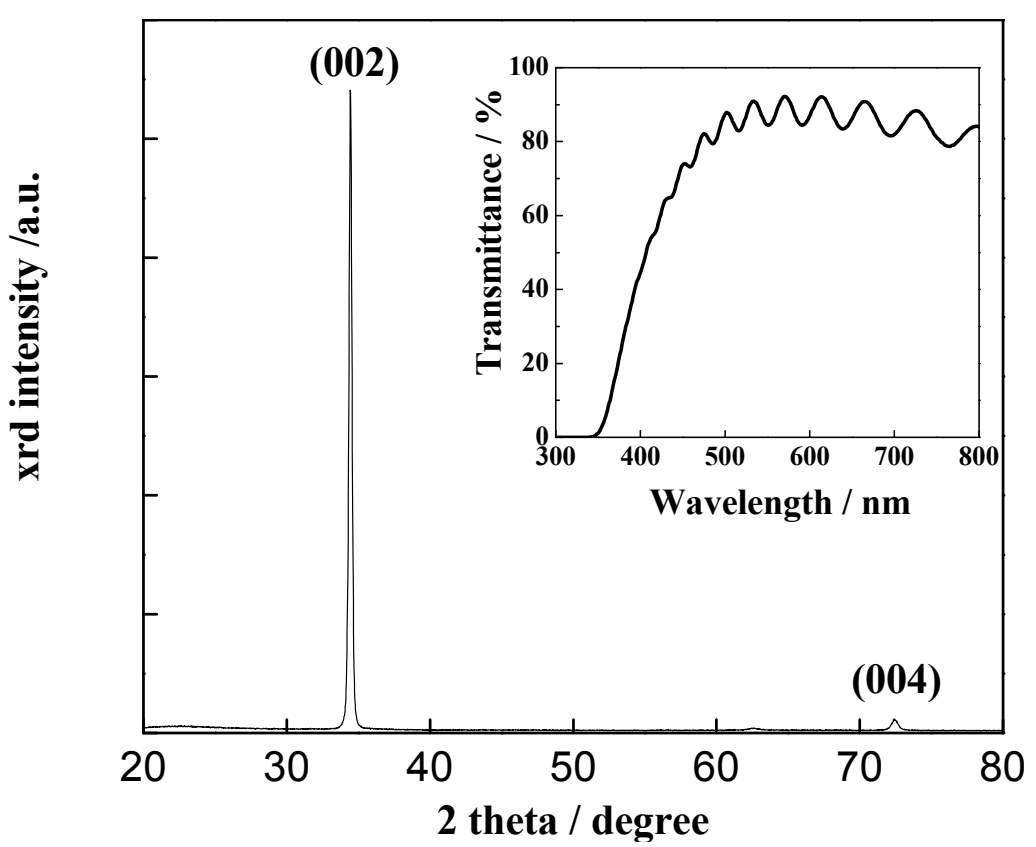

Figure 1. XRD pattern of the AZO film used as a transparent conductive substrate in $\mathrm{ZnO}$ dye-sensitized solar cells. Inset is the transmittance spectrum of the AZO film measured at room temperature 
Figure 1 shows the X-ray diffraction (XRD) pattern of the as-grown AZO film prepared by rf magnetron sputtering. The XRD pattern revealed that, the AZO film orientation is mainly along the (002) direction. The inset in Figure 1 is the transmittance spectrum of the same AZO film with an average transmittance of $82 \%$ within the wavelength range of $400-800 \mathrm{~nm}$.

The chemical structures of the indoline dyes (D149 and D205) used in the sensitization of ZnO films in this work are shown in Figure 2. The D205 dye is designed by introducing an octyl substitute, in place of ethyl group, into the rhodanine ring of the D149. Indoline dyes have also been previously used to sensitized oxide semiconductors such as $\mathrm{TiO}_{2}$ (Ito et al., 2008) and $\mathrm{SnO}_{2}$ (Onwona-Agyeman et al., 2006; Ariyasinghe et al., 2011).
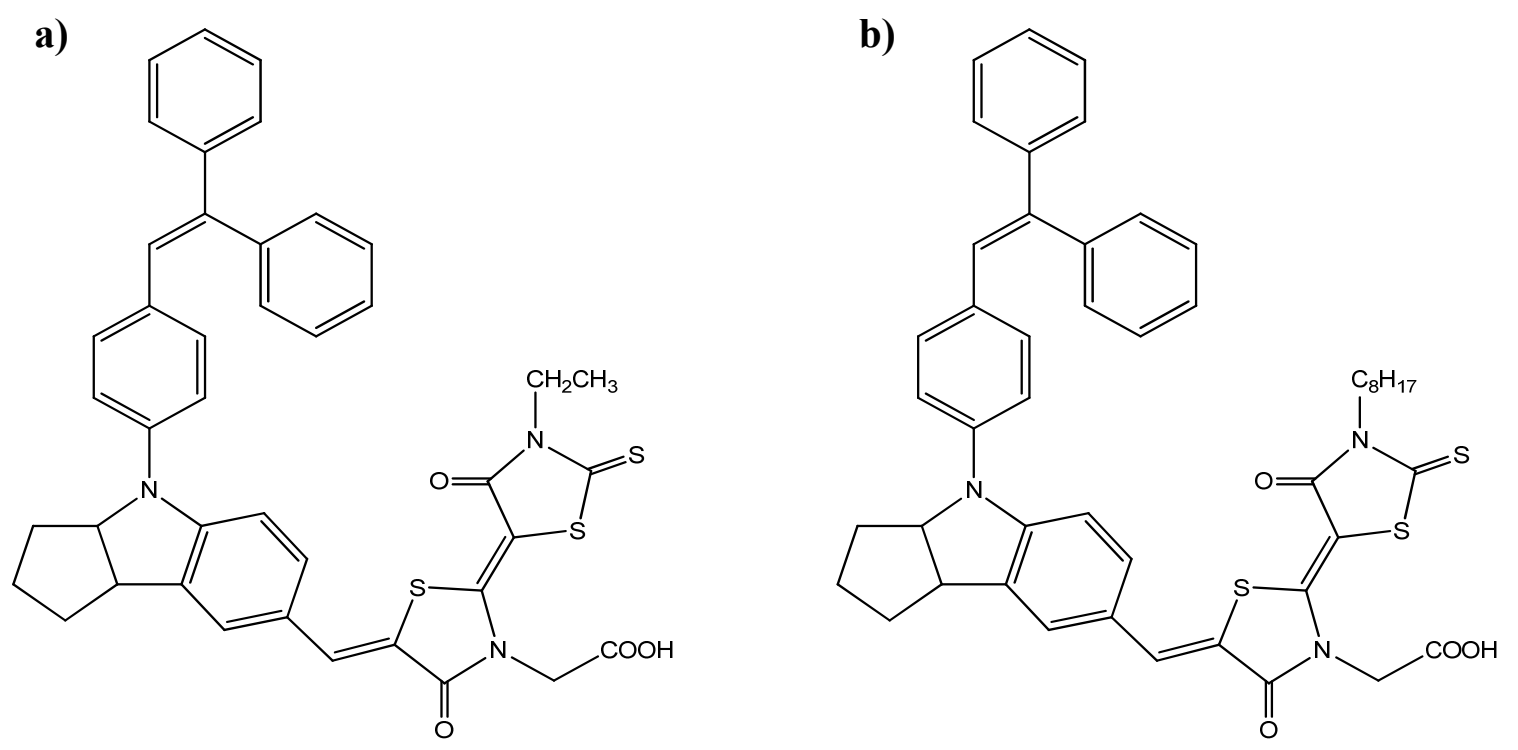

Figure 2. Chemical structures of the indoline dyes used in the sensitization of ZnO electrodes: a) D149 and b) D205

Figure 3 shows the absorption spectra of the D149 and D205 dyes in dimethylformamide (DMF), and the incident photon-to-electron conversion efficiency (IPCE) spectra of the $\mathrm{ZnO}$ photoelectrodes sensitized with the indoline and ruthenium dyes are shown in Figure 4. Strong absorption band maxima of the D149 and D205 in DMF were about $530 \mathrm{~nm}$ and these values shifted significantly to higher wavelengths when the dyes were coated on the $\mathrm{ZnO}$ films as shown in Figure 4. The self-association of dyes in solution or at solid-liquid interface is a frequently encountered phenomenon in dye chemistry owing to strong intermolecular van der Waals-like attractive forces between the molecules (Lanzafame et al., 1996). It can be clearly seen in Figure 4 that light harvesting by the indoline-sensitized $\mathrm{ZnO}$ electrodes is higher while that of ruthenium-sensitized electrode is lower. From Figure 4, the IPCE for the D205 sensitized electrode is almost 80\%, that of the D149 is $60 \%$ and finally the IPCE for the N719 sensitized cell is less than 40\%. Indoline dyes are known to form dye aggregates on oxide semiconductors (due to their high extinction coefficients) and the low light harvesting of the N719 dye on the $\mathrm{ZnO}$ electrode may be due to the inability of the dye to form proper aggregates on the semiconductor surface because of low molar extinction coefficient of ruthenium complex dyes (Nazeerudin et al., 1999). 


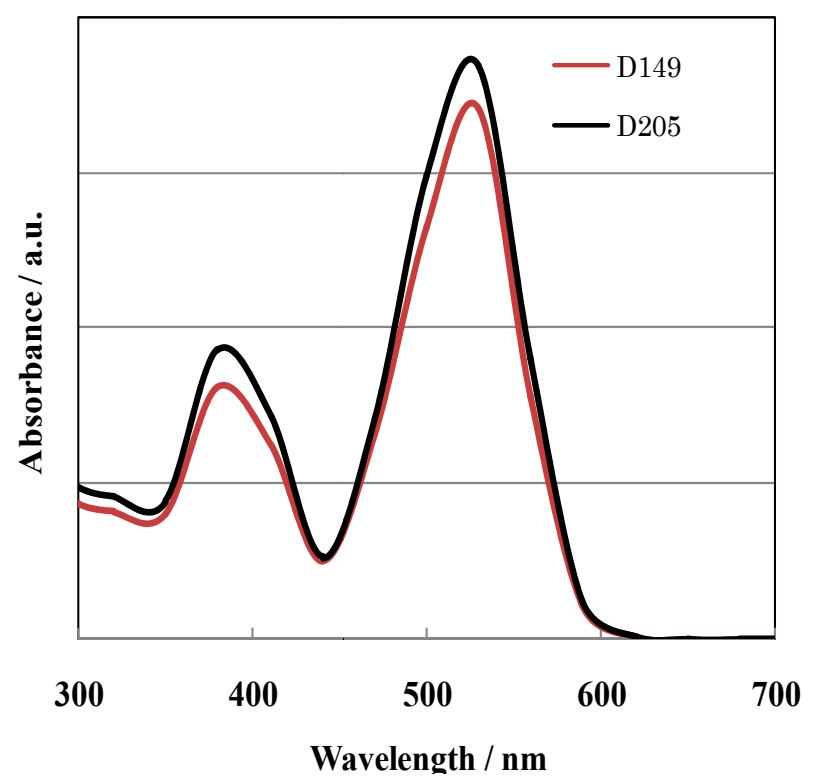

Figure 3. Absorption spectra of the indoline dyes (D149 and D205) in dimethylformamide

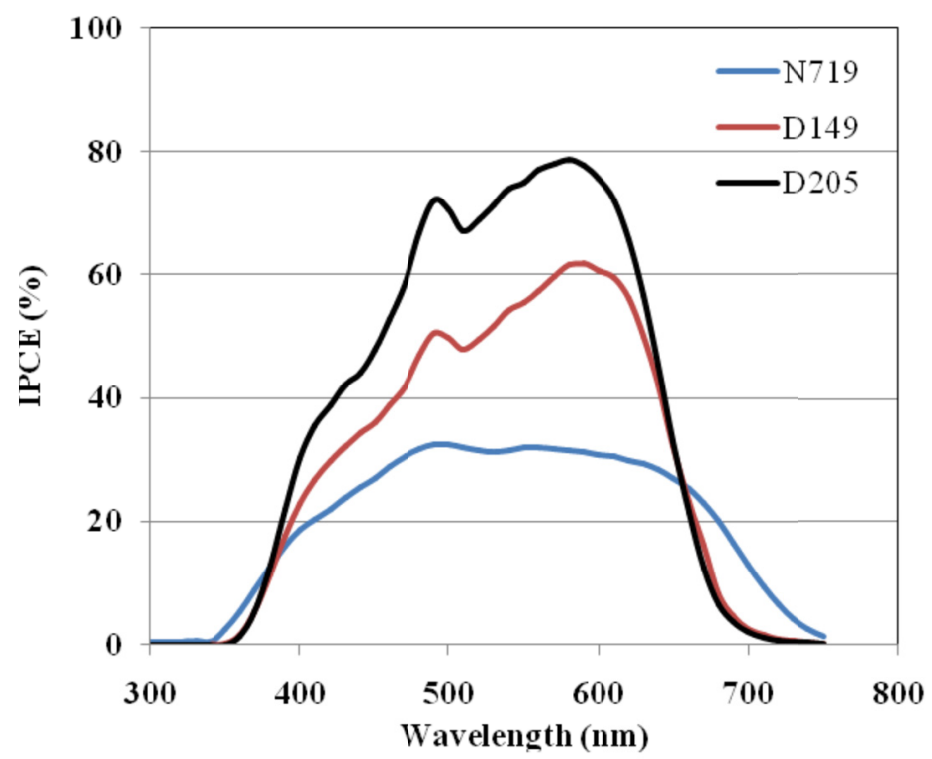

Figure 4. Photocurrent action spectra of ZnO DSCs sensitized with indoline dyes (D149 and D205) and a ruthenium complex dye (N719)

Figure 5 shows the $\mathrm{I}-\mathrm{V}$ characteristics of the $\mathrm{ZnO}$ electrodes sensitized with the indoline and ruthenium dyes and Table 1 summarizes the I-V parameters of the sensitized solar cells. From Table 1, the conversion efficiency of the D205 and D149 sensitized $\mathrm{ZnO}$ cell is 3.02 and 2.26\% respectively, which are much higher than the $0.97 \%$ recorded for the N719 sensitized cell. The other I-V parameters recorded for indoline sensitized ZnO cell are all higher than the N719 dye. The superior performance of the metal-free indoline sensitized cells can be attributed mainly to the better harvesting of light than the ruthenium complex dye. In general, the conversion of sunlight into electrical energy in a DSC begins with the absorption of significant amount of light and the subsequent injection of the photo-excited electrons into the conduction band of the porous semiconductor. 


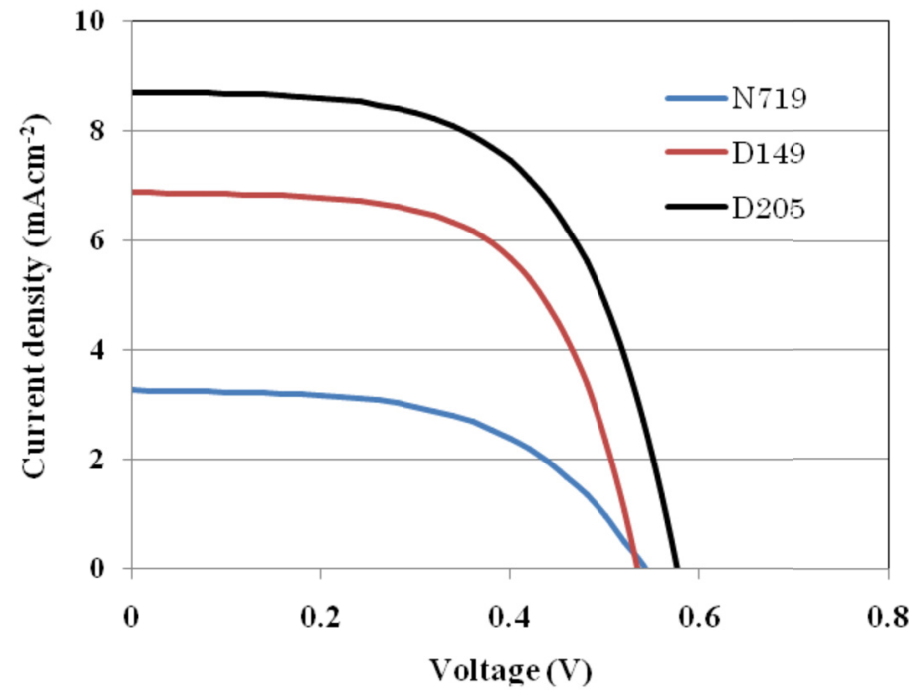

Figure 5. Photocurrent-voltage characteristics of ZnO DSCs sensitized with indoline dyes (D149 and D205) and a ruthenium complex dye (N719) under AM 1.5 simulated sunlight $\left(1000 \mathrm{~W} \mathrm{~m}^{-2}\right)$ illumination

Table 1. I-V parameters $(\mathrm{Jsc}=$ short-circuit photocurrent density, Voc $=$ open-circuit voltage, FF $=$ fill factor, $\eta$ $=$ efficiency) of $\mathrm{ZnO}$ solar cells sensitized with different dyes

\begin{tabular}{ccccc}
\hline Dye & $\begin{array}{c}\text { Jsc } \\
\left(\mathrm{mA} \mathrm{cm}^{-2}\right)\end{array}$ & $\begin{array}{c}\text { Voc } \\
(\mathrm{V})\end{array}$ & FF & $\begin{array}{c}\eta \\
(\%)\end{array}$ \\
\hline D149 & 6.87 & 0.53 & 0.62 & 2.26 \\
D205 & 8.70 & 0.58 & 0.60 & 3.02 \\
N719 & 3.26 & 0.54 & 0.55 & 0.97 \\
\hline
\end{tabular}

All the dyes (D205, D149 and N719) used in this work possess similar lowest unoccupied molecular orbitals (LUMO) and are energetically higher than the conduction band (CB) of the $\mathrm{ZnO}$ (Nazeerudin et al., 1999), as illustrated in Figure 6. This means that, all the dyes can efficiently inject electrons into the conduction band of the $\mathrm{ZnO}$ once sufficient amount of photons have been harvested. Since the amount of photons harvested by the N719 sensitized cell is low (from IPCE spectra in Figure 4), few excited electrons were injected into the conduction band of the $\mathrm{ZnO}$ as indicated by the low photocurrent yield recorded $\left(3.26 \mathrm{~mA} \mathrm{~cm}{ }^{-2}\right)$. Also, the octyl substitute in the D205 structure improved significantly the harvesting of more photons as shown in the high IPCE (almost 80\%) in Figure 4. We have previously reported that, porous $\mathrm{SnO}_{2}$ films sensitized with indoline dyes (D149 and D102) exhibited superior photovoltaic properties than $\mathrm{SnO}_{2}$ films sensitized with $\mathrm{N} 719$ dye (Onwona-Agyeman et al., 2005). However, in the case of porous $\mathrm{TiO}_{2}$ (band gap $~ 3.3 \mathrm{eV}$ ), the ruthenium complex dyes have superior photovoltaic performance than their metal-free indoline dyes. The answer may probably be due to the behavior of $\mathrm{SnO}_{2}$ (band gap $\sim 3.8 \mathrm{eV}$ ) and $\mathrm{ZnO}$ (band gap $\sim 3.3 \mathrm{eV}$ ) surfaces when they are in contact with these metal-free indoline dyes. Further work is required to investigate how these metal-free indoline dyes aggregate and interact with these oxide semiconductors. 


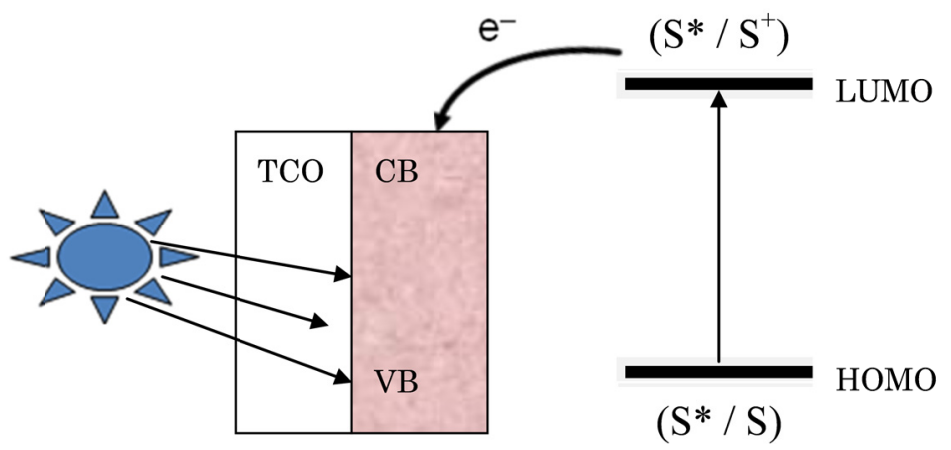

Figure 6. Diagram showing the transfer of electron from the excited state (LUMO) of the dyes used in this work to the conduction band of the nanoporous $\mathrm{ZnO}$. For efficient transfer of electrons to occur, the LUMO level must energetically be higher than the conduction band of the semiconductor

\section{Conclusion}

In summary, we have prepared dye-sensitized solar cells based on $\mathrm{ZnO}$ electrodes sensitized with metal-free indoline (D205 and D149) and a ruthenium complex (N719) dyes and evaluated their photovoltaic performance under the same experimental conditions. Aluminum-doped zinc oxide films were used as transparent conductive substrates in the solar cells to reduce thermal expansion and lattice mismatch during heat treatment. Superior solar cell performance of the indoline-sensitized $\mathrm{ZnO}$ compared with a ruthenium-sensitized $\mathrm{ZnO}$ is attributed to better dye aggregation and efficient sunlight harvesting. Conversion efficiency of 3.02\% recorded for the D205 indoline-sensitized $\mathrm{ZnO}$ solar cell with an area of $0.25 \mathrm{~cm}^{2}$ under AM 1.5 simulated sunlight, is regarded as being significant for a metal-free organic $\mathrm{ZnO}$ solar cell and proves the potential of indoline dye as sensitizers for solar cells.

\section{References}

Ariyasinghe, Y. P. Y. P., Wijayarathna, T. R. C. K., Kumara, I. G. C. K., Jayarathna, I. P. L., Thotawatthage, C. A., Gunathilake, W. S. S., ... Perera, V. P. S. (2011). Efficient passivation of $\mathrm{SnO}_{2}$ nano crystallites by indoline D-149 via dual chelation. Journal of Photochemistry and Photobiology. A: Chemistry, 217, 249-252. http://dx.doi.org/10.1016/j.jphotochem.2010.10.017

Chen, G., Zheng, K., Mo, X., Sun, D., Meng, Q., \& Chen, G. (2010). Metal-free indoline dye sensitized zinc oxide nanowires solar cell. Materials Letters, 64, 1336-1339. http://dx.doi.org/10.1016/j.matlet.2010.03.037

Chen, H. W., Lin, C. Y., Lai, Y. H., Chena, J. G., Wang, C. C., Hu, C. W., .. Ho, K. C. (2011). Electrophoretic deposition of $\mathrm{ZnO}$ film and its compression for a plastic based flexible dye-sensitized solar cell. Journal of Power Sources, 196, 4859-4864. http://dx.doi.org/10.1016/j.jpowsour.2011.01.057

Chiba, Y., Islam, A., Watanabe, Y., Komiya, R., Koide, N., \& Han, L. (2006). Dye-sensitized solar cells with conversion efficiency of 11.1\%. Japanese Journal Applied Physics, 45, L638. http://dx.doi.org/10.1143/JJAP.45.L638

Grätzel, M. (2004). Conversion of sunlight to electric power by nanocrystalline dye-sensitized solar cells. Journal of Photochemistry and Photobiology A: Chemistry, 164, 3-14. http://dx.doi.org/10.1016/j.jphotochem.2004.02.023

Guerin, V. M., Magne, C., Pauporte, Th., Bahers, T. L., \& Rathousky, J. (2010). Electrodeposited nanoporous versus nanoparticulate $\mathrm{ZnO}$ films of similar roughness for dye-sensitized solar cell applications. ACS Applied Materials \& Interfaces, 3677-3685. http://dx.doi.org/10.1021/am1008248

Hirahara, N., Onwona-Agyeman. B., \& Nakao, M. (2012). Preparation of Al-doped ZnO as transparent conductive substrate in Dye-sensitized solar cell. Thin Solid Films, 520, 2123-2127. http://dx.doi.org/10.1016/j.tsf.2011.08.100

Ito, S., Miura, H., Uchida, S., Takata, M., Sumioka, K., Liska, P., ... Grätzel, M. (2008). High efficiency organic dye sensitized solar cells with a novel indoline dye. Chemical Communication, 5194-5196. http://dx.doi.org/10.1039/b809093a 
Ito, S., Zakeeruddin, S. M., Humphry-Baker, R., Liska, P., Charvet, R., Comte, P., ... Grätzel, M. (2006). High-efficiency organic-dye-sensitized solar cells controlled by nanocrystalline- $\mathrm{TiO}_{2}$ electrode thickness. Advanced Materials, 18, 1202-1205. http://dx.doi.org/10.1002/adma.200502540

Lanzafame, J. M., Muenter, A. A., \& Brumbaugher, D. V. (1996). The effect of J-aggregate size on photo-induced charge transfer processes for dye-sensitized silver halides. Chemical Physics, 210, 79-89. http://dx.doi.org/10.1016/0301-0104(96)00121-8

Nazeeruddin, M. K., De Angelis, F., Fantacci, S., Selloni, A., Viscardi, G., Liska, P., ... Grätzel, M. (2005). Combined experimental and DFT-TDDFT computational study of photoelectrochemical cell with ruthenium sensitizers. Journal of the American Chemical Society, 127, 16835-16847. http://dx.doi.org/10.1021/ja0524671

Nazeeruddin, M. K., Kay, A., Rodicio, I., Humphry-Baker, R., Mueller, E., Liska, P. N., ... Grätzel, M. (1993). Conversion of light to electricity by cis-x2bis(2,2'-bipyridyl-4,4'-dicarboxylate) ruthenium (II) charge-transfer sensitizers $(\mathrm{x}=\mathrm{Cl}-\mathrm{Br}-\mathrm{I}-\mathrm{-}, \mathrm{CN}-$ and $\mathrm{SCN})$ on nanocrystalline titanium dioxide electrodes. Journal of American Chemical Society, 115, 6382-6390. http://dx.doi.org/10.1021/ja00067a063

Nazeeruddin, M. K., Pechy, P., Renouard, T., Zakeeruddin, S. M., Humphry-Baker, R., Comte, P., ... Grätzel, M. (2001). Engineering of efficient panchromatic sensitizers for nanocrystalline $\mathrm{TiO}_{2}$-based solar cells. Journal of the American Chemical Society, 123, 1613-1624. http://dx.doi.org/10.1021/ja003299u

Nazeeruddin, M. K., Zakeeruddin, S. M., Humphry-Baker, R., Jirousek, M., Lisker, P., Shklover, V., ... Grätzel, M. (1999). Acid-base equilibria of (2,2'-bipyridyl-4,4'-dicarboxylic acid)ruthenium(II) complexes and the effect of protonation on charge-transfer sensitization of nanocrystalline titania. Inorganic Chemistry, 38, 6298-6305. http://dx.doi.org/10.1021/ic990916a

Onwona-Agyeman, B., Kaneko, S., Kumara, A., Okuya, M., Murakami, K., Konno, A., ... Tennakone, K. (2005). Sensitization of nanocrystalline $\mathrm{SnO}_{2}$ films with indoline dyes. Japanese Journal of Applied Physics, 44, L731-L733. http://dx.doi.org/10.1143/JJAP.44.L731

Onwona-Agyeman, B., Nakao, M., Kohno, T., Liyanage, D., Murakami, K., \& Kitaoka, T. (2013). Preparation and characterization of sputtered aluminum and gallium co-doped $\mathrm{ZnO}$ thin films as conductive substrates in dye-sensitized solar cells. Chemical Engineering Journal, 219, 273-277. http://dx.doi.org/10.1016/j.cej.2013.01.006

Tefashe, U. M., Loewenstein, T., Miura, H., Schlettwein, D., \& Wittstock, G. (2010). Scanning electrochemical microscope studies of dye regeneration in indoline (D149)-sensitized $\mathrm{ZnO}$ photoelectrochemical cells. Journal of Electroanalytical Chemistry, 650, 24-30. http://dx.doi.org/10.1016/j.jelechem.2010.09.014

Wang, P., Klein, C., Humphry-Baker, R., Zakeeruddin, S. M., \& Grätzel, M. (2005). A high molar extinction coefficient sensitizer for stable dye-sensitized solar cells. Journal of the American Chemical Society, 127, 808-809. http://dx.doi.org/10.1021/ja0436190

Wang, P., Zakeeruddin, S. M., Moser, J. E., Nazeeruddin, M. K., Sekiguchi, T., \& Grätzel, M. (2002). High efficiency dye-sensitized nanocrystalline solar cells based on ionic liquid polymer gel electrolyte. Chemical Communications, 2972-2973. http://dx.doi.org/10.1039/b209322g

Wang, P., Zakeeruddin, S. M., Moser, J. E., Nazeerudin, M. K., Sekiguchi, T., \& Grätzel, M. (2003). A stable quasi-solid-state dye-sensitized solar cell with an amphiphilic ruthenium sensitizer and polymer gel electrolyte. Nature Materials, 2, 402-407. http://dx.doi.org/10.1038/nmat904

\section{Copyrights}

Copyright for this article is retained by the author(s), with first publication rights granted to the journal.

This is an open-access article distributed under the terms and conditions of the Creative Commons Attribution license (http://creativecommons.org/licenses/by/3.0/). 